Members. Antigua and Barbuda, Dominica, Grenada, Montserrat, St Kitts and Nevis, St Lucia, St Vincent and the Grenadines. The British Virgin Islands and Anguilla have associate membership.

Functions. As set out in the Treaty of Basseterre: to promote co-operation among the member states and to defend their sovereignty, territorial integrity and independence; to assist member states in the realization of their obligations and responsibilities to the international community with due regard to the role of international law as a standard of conduct in their relationships; to assist member states in the realization of their obligations and responsibilities to the international community with due regard to the role of international issues; to establish and maintain, where possible, arrangements for joint overseas representation and common services; to pursue these through its respective institutions by discussion of questions of common concern and by agreement on common action.

OECS's work is carried out by four main divisions. They have responsibility for: Corporate Services, Functional Co-operation, Economic Affairs, and External Relations. These oversee the work of a number of specialized institutions, work units and projects in six countries. There is an OECS secretariat in St Lucia, which is comprised of several operating units, responsible for the following functions: Education and Human Resource Development, Export Development Unit, Legal Unit, Environment and Sustainable Development Unit, Pharmaceutical Procurement Service, Social Development Unit and OECS Sports Desk.

Official language: English.

Headquarters: Morne Fortune, PO Box 179, Castries, St Lucia.

Website: http://www.oecs.org

e-mail: oecs@oecs.org

Director-General: Dr Len Ishmael (St Lucia).

\title{
EASTERN CARIBBEAN CENTRAL BANK (ECCB)
}

The Eastern Caribbean Central Bank was established in 1983, replacing the East Caribbean Currency Authority (ECCA). According to its Articles of Agreement, its purpose is to regulate the availability of money and credit; to promote and maintain monetary stability; to promote credit and exchange conditions and a sound financial structure conducive to the balanced growth and development of the economies of the territories of the participating Governments; and to actively promote, through means consistent with its other objectives, the economic development of the territories of the participating Governments.

Members: Anguilla, Antigua and Barbuda, Dominica, Grenada, Montserrat, St Kitts and Nevis, St Lucia, St Vincent and the Grenadines.

Offficial language: English.

Headquarters: PO Box 89, Bird Rock, Basseterre, St Kitts and Nevis.

Website: http://www.eccb-centralbank.org/

e-mail: eccbinfo@caribsurf.com

Governor: Sir Dwight Venner (St Vincent and the Grenadines).

\section{AGENCY FOR THE PROHIBITION OF NUCLEAR WEAPONS IN LATIN AMERICA AND THE CARIBBEAN (OPANAL)}

The Agency (Organismo para la Proscripción de las Armas Nucleares en la América Latina y el Caribe) was established following the Cuban missile crisis to guarantee 